\title{
Effect of imaging time on post stress left ventricular ejection fraction and volume measures by gated myocardial perfusion single photon emission computed tomography
}

\author{
Görüntüleme zamanının gated miyokard perfüzyon tek foton emisyon \\ bilgisayarlı tomografisi ile ölçülen sol ventrikül ejeksiyon fraksiyonu ve \\ hacimleri üzerine etkisi
}

\author{
Zeki Dostbil ${ }^{1}$, Mehmet Ali Elbey², Zuhal Arıtürk², Habib Çil'², Ebru Tekbaş², Bekir Taşdemir ${ }^{3}$ \\ 'Dicle University Medical Faculty, Department of Nuclear Medicine, Diyarbakır, \\ ${ }^{2}$ Dicle University Medical Faculty, Department of Cardiology, Diyarbakır,

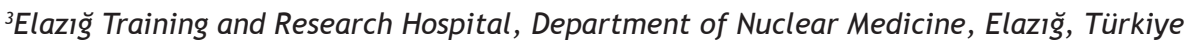

\section{ÖZET}

Amaç: Efor sonrası sol ventrikül ejeksiyon fraksiyonu (LVEF) ve sol ventrikül volüm değerlerinin koroner arter hastalığı bulunan hastalardaki kardiyak ölüm tahmininde katkısı vardır. Bu çalışmada, efor sonrası görüntüleme zamanının Quantitative Gated SPECT (QGS-Cedars-Sinai) programı ile hesaplanan efor sonrası LVEF, end-diastolik volüm (EDV) ve end-sistolik volüm (ESV) üzerine etkisini araştırmayı amaçladık.

Hastalar ve yöntem: Bu çalışma 2008 ve 2009 yıllarında Elazığ Eğitim ve Araştırma Hastanesi Nükleer Tıp Birimine göğüs ağrısı nedeniyle Kardiyoloji Kliniğinden gönderilen 36 hasta üzerinde yapıldı. Tüm hastalara efor esnasında yapılan 99mTc-Mibi enjeksiyonunu takiben 20. ve 40 . dakikalarda EKG-gated (8-bin frame modunda) miyokard perfüzyon SPECT sintigrafisi uygulandı. Kardiyak kantifikasyon yazılımı olan QGS programı kullanılarak LVEF, EDV ve ESV hesaplandı. İlk ve ikinci görüntülemelerden elde edilen LVEF, EDV ve ESV değerleri istatistiksel olarak birbirleri ile karşılaştırıldı.

Bulgular: Illk ve ikinci görüntülemelerden elde edilen LVEF, EDV ve ESV değerleri arasında istatistiksel olarak anlamlı farklılık bulunmadı ( $p>0.05)$.

Sonuç: Efor sonrası sol ventrikül fonksiyon parametreleri koroner arter hastalığı bulunan hastalardaki prognoz değerlendirmesinde önemlidir. Efor bitiminden 20-40 dakika sonra yapılan miyokard perfüzyon SPECT sintigrafisi efor sonrası LVEF, EDV ve ESV değerleri açısından tekrarlanabilir değerler vermektedir. Klin Den Ar Derg 2010; 1(3): 177-181

Anahtar kelimeler: Kardiyak gated SPECT, sol ventrikül fonksiyonu, görüntüleme, QGS

\section{ABSTRACT}

Objectives: Post-stress left ventricular ejection fraction (LVEF) and LV volumes have incremental value in predicting cardiac death (CD) in patients with coronary artery disease. In this study, we aimed to investigate the effect of imaging time after exercise on post-stress LVEF, enddiastolic volume (EDV) and end-systolic volume (ESV) calculated by cardiac quantification software program called Quantitative Gated SPECT (QGS-Cedars-Sinai).

Materials and methods: This study was consisted of 36 patient referred to Nuclear Medicine Department from Cardiology Clinics because of chest pain in 'Elazig Research and Training Hospital' in 2008-2009. In all patients, ECG Gated (8-bin frame mode) myocardial perfusion SPECT scintigraphy was performed 20 and 40 min later following 99mTc-Mibi injection during exercise. By means of the cardiac quantification software program called Quantitative Gated SPECT (QGS-Cedars-Sinai); LVEF, EDV and ESV were calculated. LVEF, EDV and ESV values obtained from initial and second acquisition were compared statistically.

Results: There was no statistically significant difference between post-stress LVEF, EDV and ESV measures of initial and second acquisition ( $p>0.05$ ).

Conclusion: Left ventricular functional parameters after exercise are important for assess prognosis in patients with CAD. Post-stress LVEF, EDV and ESV measured on gated myocardial perfusion SPECT images within 20-40 min after completion of exercise give reproducible information. J Clin Exp Invest 2010; 1(3): 177-181

Key words: Cardiac gated SPECT, left ventricular function, imaging, QGS

Yazıșma Adresi /Correspondence: Dr. Zeki Dostbil, Dicle University Medical Faculty, Department of Nuclear Medicine, Diyarbakir, Türkiye Email: zekidostbil@yahoo.com

Geliș Tarihi / Received: 07.09.2010, Kabul Tarihi / Accepted: 19.10.2010

Copyright @ Klinik ve Deneysel Araștırmalar Dergisi 2010, Her hakkı saklıdır / All rights reserved 


\section{INTRODUCTION}

ECG-gated myocardial perfusion single photon emission computed tomography (SPECT) is widely used in evaluation of myocardial ischemia, infarct, assessment of myocardial viability and risk stratification for patients with coronary artery disease. Gated myocardial perfusion SPECT (MPS) also provide information about left ventricular functional parameters such as wall motion, left ventricular ejection fraction (LVEF), end-diastolic volume (EDV) and end-systolic volume (ESV). ${ }^{1,2}$ (Figure 1). Cardiac magnetic resonance imaging (MR) is considered reference method for LV functional parameters. In many studies in which measures of functional parameters by MR and gated myocardial perfusion SPECT were compared have shown good concordance of these two methods. ${ }^{3-5}$

In many studies it has been shown that poststress LVEF and LV volumes have incremental value in predicting cardiac death (CD) ${ }^{6}$ Cardiac death rate was a function of the extent and severity of perfusion defects at stress on MPS (7). However, further risk stratification by LVEF demonstrated mortality rate increases as post-stress LVEF decreases. ${ }^{6}$ It has been also shown that left ventricular EDV and ESV were highly significant predictors of CD.,

In guidelines, it has been advocated that the post-stress MPS imaging should begin 15-60 min after $99 \mathrm{mTc}-\mathrm{MIBI}$ injection during exercise. ${ }^{9}{ }^{10}$ In several studies, it has been reported that after completion of the stress, ischemic LV dysfunction may have persisted for a time period ranged from immediate to $30 \mathrm{~min}^{8}{ }^{8,13}$ In most centers, post-stress imaging procedure is initiated at the time point between 20 to 60 minute after $99 \mathrm{mTc}-\mathrm{MIBI}$ injection. In this study we aimed to investigate that whether the time of 20 and 40 minute to start imaging after $99 \mathrm{mTc}-$ MIBI injection affect post-stress LVEF, EDV and ESV measures using ECG-gated myocardial perfusion SPECT.

\section{MATERIALS AND METHODS}

Thirty six patients (16 male, 20 female and mean age: $54 \pm 13$ years) who were referred from Cardiology Clinics to Nuclear Medicine Department for known or suspected coronary artery disease in Elaziğ Training and Research Hospital in 2008-2009 were included in this study. ECG-gated myocardial perfusion SPECT scintigraphy was performed 20 min later following 99mTc-MIBI injection during peak physiological exercise on treadmill. Bruce or Modified Bruce protocol was used.

Following initial acquisition was completed; patients were instructed to relax for a while, then repositioned on the patient table and reimaged by the same acquisition procedure about 40 minute later following 99mTc-MIBI injection. Double headed 'GE-infinia gamma camera' (GE Medical Systems, Milwaukee, WI, USA) equipped with a low-energy high-resolution collimator was used for imaging. 60 images at 30 projections, $25 \mathrm{sec}$ per projection, were acquired over $180 \mathrm{o}$ (45o right anterior oblique to 135 o left posterior oblique) on a $64 \times 64$ matrix. ECG-gating was acquired in 8 frames per cardiac cycle and attenuation or scatter correction was not performed. By means of cardiac quantification software called QGS (Cedars-Sinai Los Angeles, CA, USA; version 3.0) post-stress LVEF, EDV and ESV were calculated on two raw data of initial and second imaging for each patient. Filtered back-projection (FBP) reconstruction was performed with a low pass Butterworth filter (cut-off 0.52; power 5.0) and pixel size of $6.43 \mathrm{~mm}$.

Statistical analysis was performed using the SPSS 15.0 software program (SPSS Inc., Chicago, Illinois, USA). Measures of LVEF, EDV and ESV values obtained from first and second acquisition were compared statistically with the paired Student's t-test and the Wilcoxon signed ranks test. $\mathrm{P}$ value of less than 0.05 was considered as statistically significant.

\section{RESULTS}

On MPS images, all patients had reversible perfusion defects at various degrees. Left ventricular functional parameters of all patients were shown on Table 1. In statistical analyses, there was not statistically significant difference between post-stress LVEF, EDV and ESV values obtained from QGS software $(\mathrm{p}>0.05)$ (Figure 2). There was also not significant difference between LV volumetric parameters of male and female patients $(\mathrm{p}>0.05)$. 
Table 1. Post-stress LVEF, EDV and ESV measures of 36 patients obtained from QGS software, Mean \pm SD (range)

\begin{tabular}{cll}
\hline & 1st acquisition & 2nd acquisition \\
\hline LVEF (\%) & $71.7 \pm 7.9(43-85)$ & $70.1 \pm 8.3(43-82)$ \\
Male & $68.1 \pm 4.7(61-79)$ & $68.8 \pm 6.9(59-81)$ \\
Female & $74.6 \pm 8.8(43-85)$ & $71.3 \pm 9.3(43-82)$ \\
\hline EDV (ml) & $97.7 \pm 20.8(60-147)$ & $97.9 \pm 20.2(62-151)$ \\
Male & $94.9 \pm 19.7(60-128)$ & $99.4 \pm 21.7(62-151)$ \\
Female & $99.9 \pm 21.8(60-147)$ & $96.7 \pm 19.4(62-132)$ \\
\hline ESV (ml) & $28.4 \pm 12.9(11-84)$ & $30 \pm 12.8(12-78)$ \\
Male & $30.6 \pm 8.9(13-49)$ & $30.8 \pm 14.6(12-51)$ \\
Female & $26.6 \pm 15.4(11-84)$ & $28.9 \pm 14.6(12-78)$ \\
\hline
\end{tabular}

LVEF: left ventricular ejection fraction, EDV: end-diastolic volume

ESV: end-systolic volume

\section{DISCUSSION}

It was shown that post-stress LVEF and LV volumes calculated by gated myocardial perfusion SPECT provide incremental data over perfusion and clinical information in the prediction of CD as well as the combined endpoint of CD or myocardial infarction. 6, 8,12,13 Post-stress LVEF and CD rate are in relation exponentially, with a progressive increase in mortality as LVEF falls below 50\%.,12 It has been concluded that the amount of ischemia detected on MPS was the best predictor of nonfatal MI, and the post-stress LVEF measured by gated myocardial perfusion SPECT was the best predictor of CD. ${ }^{6}$

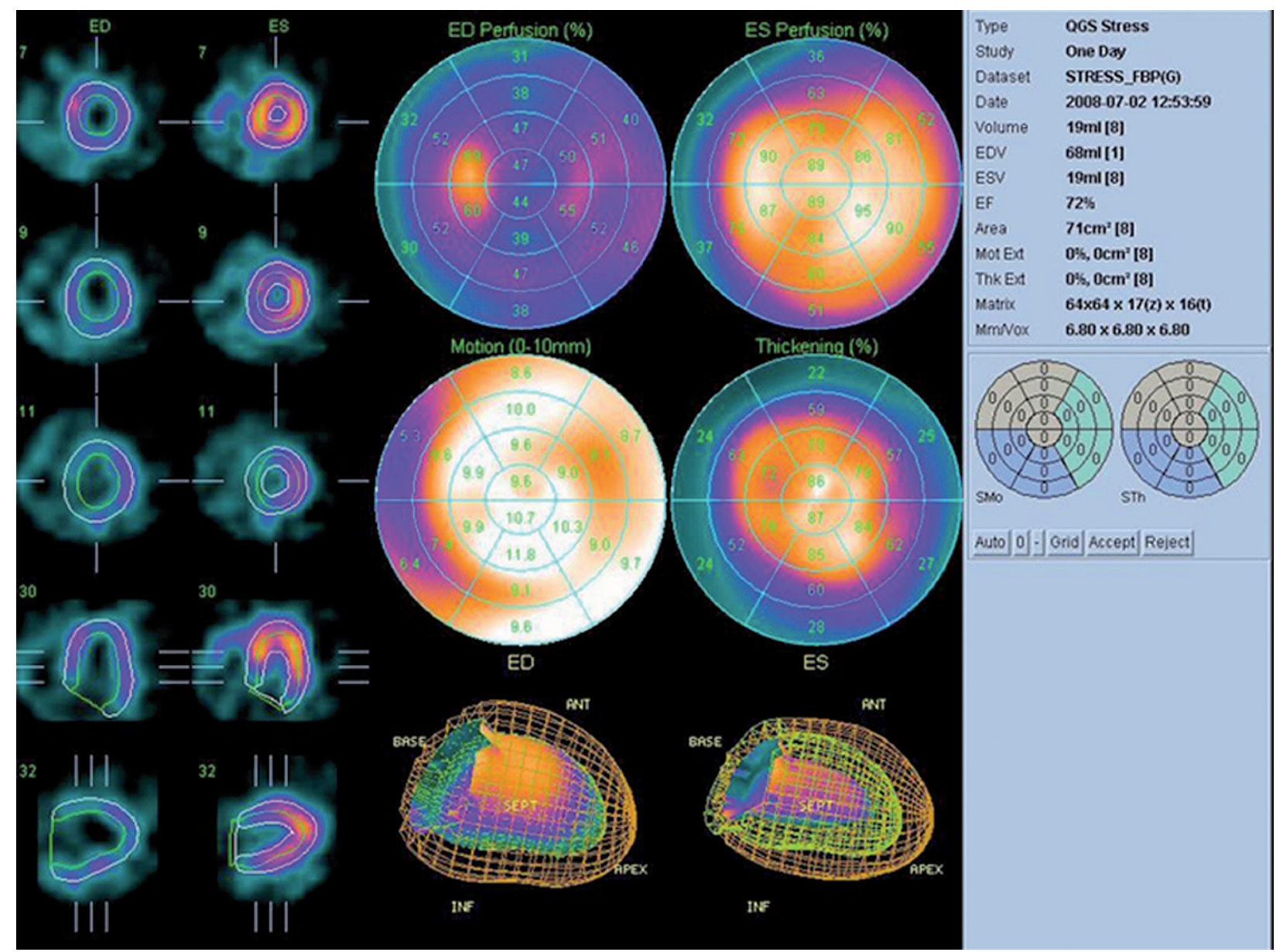

Figure 1. Cardiac quantification data of 39 year old male with normal myocardial perfusion on myocardial perfusion scintigraphy is seen above. 


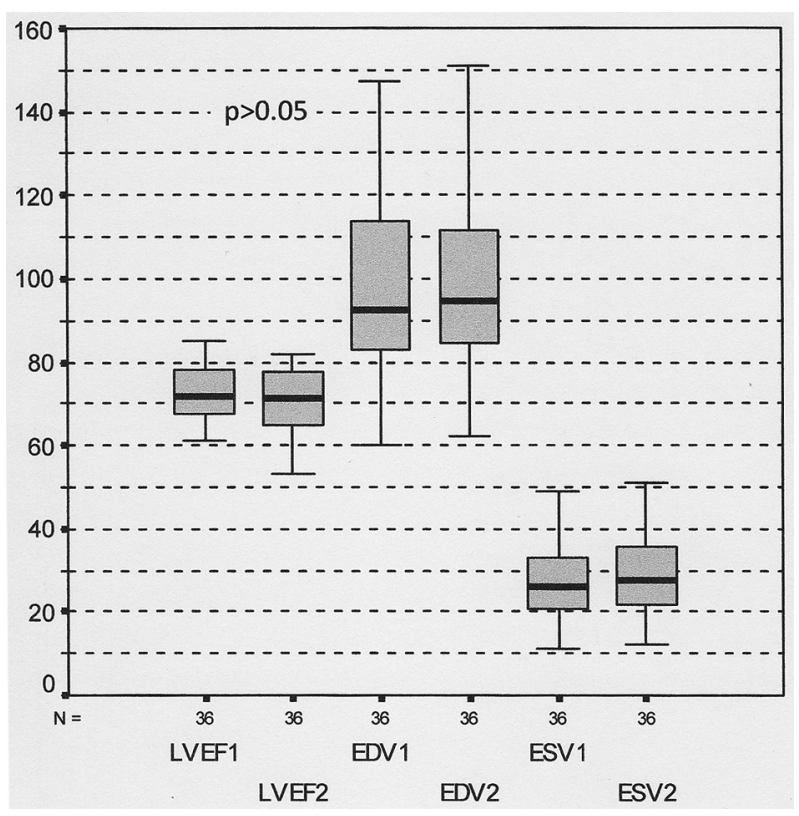

Figure 2. Post-stress LVEF, EDV and ESV of first and second acquisition

Lynne et al. ${ }^{11}$ have designed a study to investigate whether LVEF calculated from post-stress SPECT reflects the basal value for LVEF or poststress LVEF is reduced in some patients with stressinduced ischemia. In patients with reversible perfusion defects, post-stress LVEF was $>5 \%$ lower than that at rest, whereas in the patients with normal myocardial perfusion or fixed perfusion defect poststress LVEF was either $\pm 5 \%$ greater than that at rest. They have concluded that post-ischemic stunning could affect post-stress LVEF. Age, gender, previous MI, tracer used and type of stress don't cause differences between LVEF at post-stress and resting period. ${ }^{11,14}$ However, in some studies it has been suggested that the post-stress LVEF is significantly lower than the LVEF at rest in patients with ischemia or without ischemia. ${ }^{15}$

In some studies using gated blood pool imaging, ischemic LV dysfunction manifested by global reduction of LVEF resolves rapidly after exercise. Those studies were performed during and immediately following upright or semi supine bicycle exercise in patients with CAD. It was found that LVEF rises during the early phases of exercise, then falls at the ischemia threshold and rises again immediately after stress. ${ }^{11,16-18}$ Whereas the other studies using serial gated blood pool imaging combined with echocardiography in patients with angiographically proven CAD indicated that LV dysfunction may persist up to 2 hours after completion of exercise..$^{11,19-21}$

In our study, we acquired images at 20 and 40 min after completion of exercise. Acquisition lasted about 13 min. All patients in our study had reversible perfusion defects. We didn't find statistical differences between post-stress LVEF and LV volume measures at $20^{\text {th }}$ and $40^{\text {th }}$ min acquisition ( $\mathrm{p}>0.05$ ). Data from male or female patients gave similar results $(p>0.05)$. These findings have shown that acquisition within 20-40 min time interval after exercise completion is suitable to measure post-stress LVEF and LV volumes, and imaging within 20-40 min at post-stress period doesn't reveal different results.

In conclusion, our findings have shown that the gated myocardial perfusion SPECT imaging after 99mTc-MIBI injection during exercise within 2040 min give reproducible measures of post-stress LVEF and LV volumes.

\section{Disclosure}

The authors declare that they have no financial relationship with any organization related to the research and no conflict of interest.

\section{REFERENCES}

1. Tout DA, Rogers A, Van Aswegen A, Underwood SR. Left ventricular function parameters obtained from gated myocardial perfusion SPECT imaging: a comparison of two data processing systems. Nucl Med Commun 2005;26:103-7.

2. Lavender FM, Meades RT, Al-Nahhas A, Nijran KS. Factors affecting the measurement of left ventricular ejection fraction in myocardial perfusion imaging. Nucl Med Commun 2009;30:350-5.

3. Ioannidis JPA, Trikalinos TA, Danias PG. Electrocardiogramgated single-photon emission computed tomography versus cardiac magnetic resonance imaging for the assessment of left Ventricular volumes and ejection fraction. JACC 2002;39:2059-68.

4. Faber TL, Vansant JP, Pettigrew RI, et al. Evaluation of left ventricular endocardial volumes and ejection fractions computed from gated perfusion SPECT with magnetic imaging: comparison of two methods. J Nucl Cardiol 2001;8:645-51.

5. Vaduganathan $P$, He Z-X, Vick GW, Manmarian JJ, Verani MS. Evaluation of left ventricular wall motion, volumes, and ejection fraction by gated myocardial tomography with technetium 99mlabeled tetrofosmin: a comparison with cine magnetic resonance imaging. J Nucl Cardiol 1998;6:3-10.

6. Sharir T, Germano G, Kavanagh PB, et al. Incremental prognostic value of post-stress left ventricular ejection fraction and volume by gated myocardial perfusion sin- 
gle photon emission computed tomography. Circulation 1999; 100:1035-42.

7. Hachamovitch R, Berman DS, Shaw LJ, et al. Incremental prognostic value of myocardial perfusion single photon emission computed tomography for the prediction of cardiac death. Ciculation 1998;97:535-543.

8. Usui Y, Chikamori T, Nakajima K, Hida S, Yamashina A, Nishimura T. Prognostic value of post-ischemic stunning as assessed by gated myocardial perfusion single-photon emission computed tomography: a subanalysis of the JACCESS study. Circ J 2010;74:1591-9.

9. EANM/ESC procedural guidelines for myocardial perfusion imaging in nuclear cardiology (2005).

10. SNM procedure guideline for myocardial perfusion imaging 3.3 (2008).

11. Lynne LJ, Facc SA, Verdesca WY, et al. Postischemic Stunning Can Affect Left Ventricular Ejection Fraction and Regional Wall Motion on Post-Stress Gated Sestamibi Tomograms. J Am Coll Cardiol 1997;30:1641-8.

12. Sharir T, Germano G, Kang X, et al. Prediction of myocardial infarction versus cardiac death by gated myocardial perfusion SPECT: risk stratification by the amount of stress-induced ischemia and the poststress ejection fraction. J Nucl Med 2001;42:831-837.

13. Denollet J, Brutsaert DL. Personality, disease severity, and the risk of long-term cardiac events in patients with a decreased ejection fraction after myocardial infarction. Circulation 1998;97:167-173.

14. Ababneh AA, Sciacca RR, Kim B, Bergmann SR. Normal limits for left ventricular ejection fraction and volumes estimated with gated myocardial perfusion imaging in patients with normal exercise test results: Influence of tracer, gender, and acquisition camera. J Nucl Cardiol 2000;7:661-8.
15. Borges-Neto S, Javaid A, Shaw LK, et al. Poststress measurements of left ventricular function with gated perfusion SPECT: comparison with resting measurements by using a same-day perfusion-function protocol. Radiology 2000;215:529-33.

16. Rozanski A, Elkayam U, Berman DS, Diamond GA, Prause J, Swan HJC. Improvement of resting myocardial asynergy with cessation of upright bicycle exercise. Circulation 1983;67:529-35.

17. Nixon JV, Brown CN, Smitherman TC. Identification of transient and persistent segmental wall motion abnormalities in patients with unstable angina by two-dimensional echocardiography. Circulation 1982;65:1497-503.

18. Rozanski A, Berman D, Gray R, et al. Preoperative prediction of reversible myocardial asynergy by postexercise radionuclide ventriculography. N Engl J Med 1982;307:2126.

19. Ambrosio G, Betocchi S, Pace L, et al. Prolonged impairment of regional contractile function after resolution of exercise-induced angina: evidence of myocardial stunning in patients with coronary artery disease. Circulation 1996;94:2455-63.

20. Robertson S, Feigenbaum H, Armstong WF, Dillon JC, O'Donnell J, McHenry PW. Exercise echocardiography: a clinically practical addition in the evaluation of coronary artery disease. J Am Coll Cardiol 1983;2:1085-91.

21. Katz A, Force T, Folland E, Aebischer N, Sharma S, Parisi A. Echocardiographic assessment of ventricular systolic function. In: Marcus ML and Braunwald E, editors. Marcus Cardiac Imaging: a Companion to Braunwald's Heart Disease. Philadelphia: WB Saunders, 1996:297-324. 